University of Nebraska - Lincoln

DigitalCommons@University of Nebraska - Lincoln

\title{
Fate of Sulfamethoxazole, 4-Nonylphenol, and 17 $\beta$-Estradiol in Groundwater Contaminated by Wastewater Treatment Plant Effluent
}

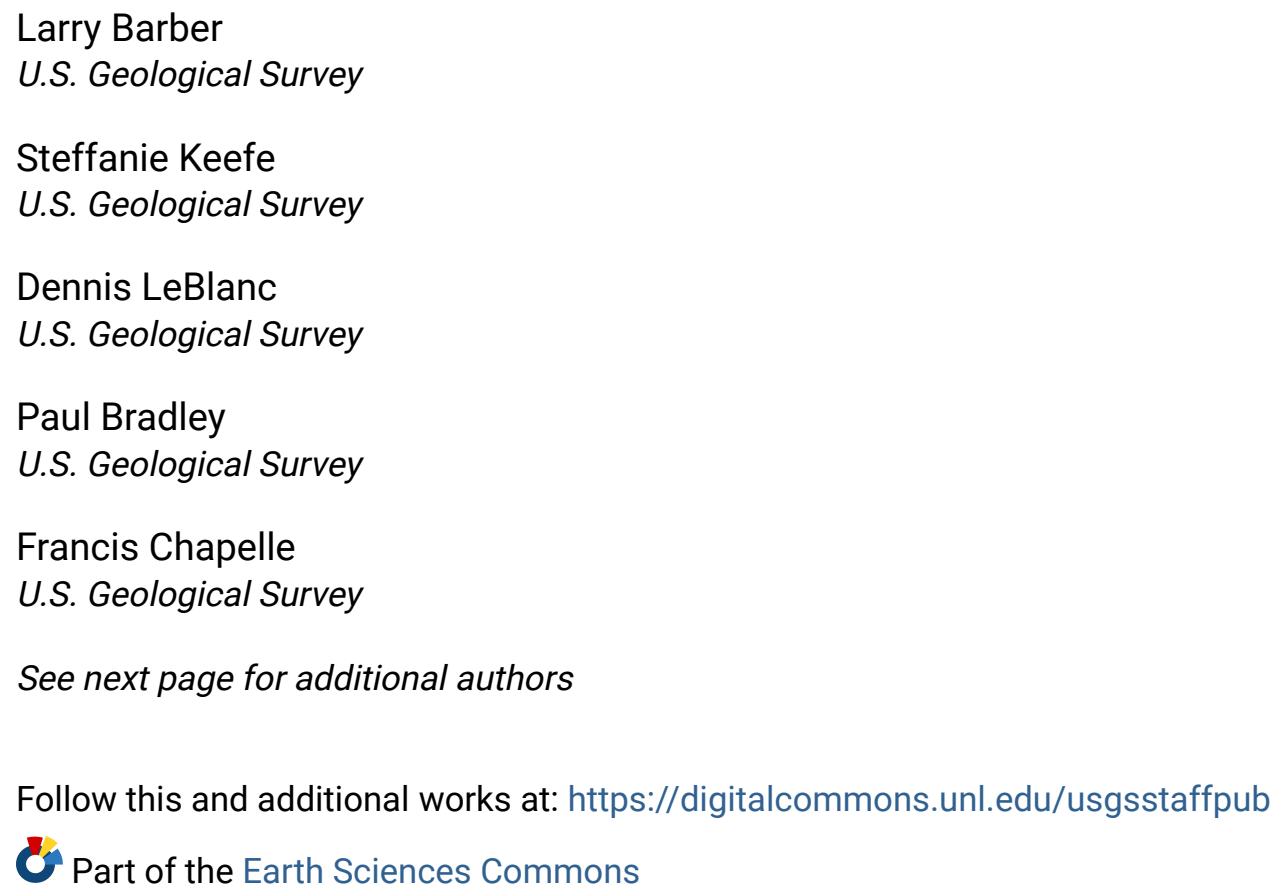

Barber, Larry; Keefe, Steffanie; LeBlanc, Dennis; Bradley, Paul; Chapelle, Francis; Meyer, Michael; Lofton, Keith; Kolpin, Dana; and Rubio, Fernando, "Fate of Sulfamethoxazole, 4-Nonylphenol, and 17 $\beta$-Estradiol in Groundwater Contaminated by Wastewater Treatment Plant Effluent" (2009). USGS Staff -- Published Research. 63.

https://digitalcommons.unl.edu/usgsstaffpub/63

This Article is brought to you for free and open access by the US Geological Survey at DigitalCommons@University of Nebraska - Lincoln. It has been accepted for inclusion in USGS Staff -- Published Research by an authorized administrator of DigitalCommons@University of Nebraska - Lincoln. 


\section{Authors}

Larry Barber, Steffanie Keefe, Dennis LeBlanc, Paul Bradley, Francis Chapelle, Michael Meyer, Keith Lofton, Dana Kolpin, and Fernando Rubio 
Fate of Sulfamethoxazole, 4-Nonylphenol, and $17 \beta$-Estradiol in Groundwater Contaminated by Wastewater Treatment Plant Effluent

LARRY B. B A R B R, *, +

STEFFANIE H. KEEFE, ${ }^{\dagger}$

DENIS R. LEBLANC, ${ }^{\ddagger}$ PAUL M. BRADLEY,

FRANCIS H. CHAPELLE, $\$$

MICHAEL T. MEYER, "KEITH A. LOFTIN,"

DANA W. KOLPIN, ${ }^{\perp}$ A N

FER N A D O R U B O *

U.S. Geological Survey, 3215 Marine Street, Boulder, Colorado 80303, U.S. Geological Survey, 10 Bearfoot Road, Northborough, Massachusetts 01532, U.S. Geological Survey, 720 Gracern Road, Suite 129, Columbia,

South Carolina 29210, U.S. Geological Survey,

4821 Quail Crest Place, Lawrence, Kansas 66049, U.S.

Geological Survey, 400 South Clinton Street, Iowa City,

Iowa 52244, and Abraxis, 54 Steamwhistle,

Warminster, Pennsylvania 18974

Received November 20, 2008. Revised manuscript received March 19, 2009. Accepted March 30, 2009.

Organic wastewater contaminants (OWCs) were measured in samples collected from monitoring wells located along a 4.5$\mathrm{km}$ transect of a plume of groundwater contaminated by 60 years of continuous rapid infiltration disposal of wastewater treatment plant effluent. Fifteen percent of the 212 OWCs analyzed were detected, including the antibiotic sulfamethoxazole (SX), the nonionic surfactant degradation product 4-nonylphenol (NP), the solvent tetrachloroethene (PCE), and the disinfectant 1,4-dichlorobenzene (DCB). Comparison of the 2005 sampling results to data collected from the same wells in 1985 indicates that PCE and DCB are transported more rapidly in the aquifer than NP, consistent with predictions based on compound hydrophobicity. Natural gradient in situ tracer experiments were conducted to evaluate the subsurface behavior of SX, $N P$, and the female sex hormone $17 \beta$-estradiol (E2) in two oxic zones in the aquifer: (1) a downgradient transition zone at the interface between the contamination plume and the overlying uncontaminated groundwater and (2) a contaminated zone located beneath the infiltration beds, which have not been loaded for 10 years. In both zones, breakthrough curves for the conservative tracer bromide $\left(\mathrm{Br}^{-}\right)$and SX were nearly coincident, whereas NP and E2 were retarded relative to $\mathrm{Br}^{-}$and showed mass loss. Retardation was greater in the contaminated zone than in the transition zone. Attenuation of NP and E2

* Corresponding author e-mail: lbbarber@usgs.gov; phone: 303541-3039.

${ }^{\dagger}$ U.S. Geological Survey, Boulder, CO.

${ }^{\ddagger}$ U.S. Geological Survey, Northborough, MA.

§ U.S. Geological Survey, Columbia, SC.

"U.S. Geological Survey, Lawrence, KS.

${ }^{\perp}$ U.S. Geological Survey, Iowa City, IA.

\# Abraxis, Warminster, PA. in the aquifer was attributed to biotransformation, and oxic laboratory microcosm experiments using sediments from the transition and contaminated zones show that uniform-ringlabeled ${ }^{14} \mathrm{C}$ 4-normal-NP was biodegraded more rapidly (30-60\% recovered as ${ }^{14} \mathrm{CO}_{2}$ in 13 days) than $4-{ }^{14} \mathrm{C}$ E2 $(20-90 \%$ recovered as ${ }^{14} \mathrm{CO}_{2}$ in 54 days). There was little difference in mineralization potential between sites.

\section{Introduction}

Reliance on wastewater treatment plant (WWTP) effluent for aquifer recharge and supplementing potable water supply (1) increases the need for understanding the occurrence and fate of organic wastewater contaminants (OWCs) in groundwater. Groundwater withdrawals in the United States during 1995 were estimated at $2.9 \times 10^{5} \mathrm{~m}^{3} \mathrm{~d}^{-1}$ and provided public water supply for over 40 million people (2). Groundwater is a major source of water for irrigation and contributes flow to streams and wetland habitats (3). There is growing concern about potential effects of OWCs on the aquatic environment (4), and their occurrence in WWTP effluents and surface waters is well documented (5-11). Less is known about the occurrence and fate of OWCs in groundwater $(12-16)$.

The chemistry of WWTP effluents is complex and has been linked to reproductive system disruption of fish living in effluent impacted streams $(17-20)$. The most potent estrogenic chemicals in WWTP effluents are steroid hormones such as the female sex hormone $17 \beta$-estradiol (E2), although nonsteroid chemicals such as the nonionic surfactant degradation product 4-nonylphenol (NP) also have estrogenic activity (21). Other OWCs, such as the antibiotic sulfamethoxazole (SX), have widespread occurrence $(8,9,22,23)$, and there is concern about their ecological effects (24) and development of antibiotic resistance in microbes (25).

This study was conducted at the U.S. Geological Survey's Cape Cod Toxic Substances Hydrology research site, an intensively investigated plume of WWTP effluent contaminated groundwater $(26,27)$. The plume contains OWCs including NP, the solvent tetrachloroethene (PCE), the disinfectant 1,4-dichlorobenzene (DCB), the anionic surfactant linear alkylbenzene sulfonate (LAS), and many other compounds $(12,28-30)$. A 3-tiered approach was used to assess OWCs in the Cape Cod groundwater contamination plume: (1) resampling monitoring wells 20 years after their original sampling in 1985, (2) conducting natural gradient in situ tracer experiments using SX, NP, and E2, and (3) conducting laboratory sediment microcosm experiments using NP and E2.

\section{Methods}

Study Site. The extensive groundwater contamination plume (Figure 1A) at the Cape Cod research site (26) results from 60 years of continuous rapid infiltration disposal of WWTP effluent (about $4.6 \times 10^{7} \mathrm{~m}^{3}$ of effluent was discharged between 1936 and 1995). The unconfined glacial outwash aquifer consists of moderately heterogeneous, fine to course grained sand and gravel, with groundwater flow to the southwest at a velocity of $0.42 \mathrm{~m} \mathrm{~d}^{-1}$, a hydraulic gradient of $1.5 \mathrm{~m} \mathrm{~km}^{-1}$, a hydraulic conductivity of $110 \mathrm{~m} \mathrm{~d}^{-1}$, a porosity of 0.39 , and a longitudinal dispersitivity (for a 300-m long tracer experiment) of $0.96 \mathrm{~m}(31,32)$. Hydraulic properties vary as a function of spatial scale (33). The aquifer sediments are relatively unweathered (deposited about 15000 years ago in the most recent glacial advance) and composed primarily of quartz and feldspars with a complex suite of accessory minerals (including glauconite, biotite, amphiboles, 
A
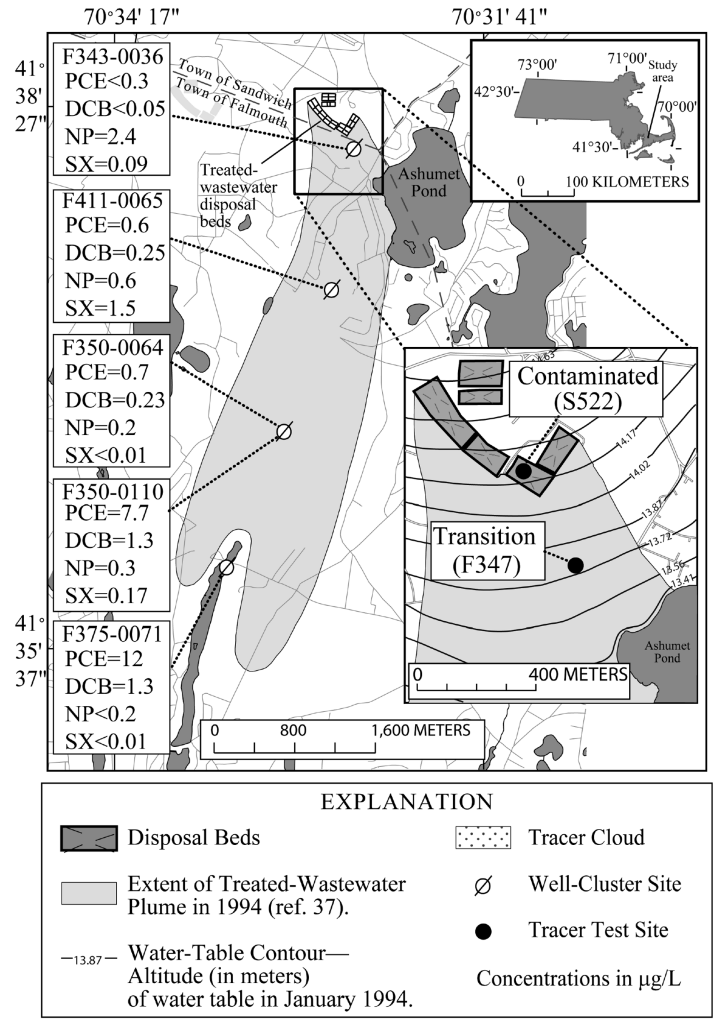

B

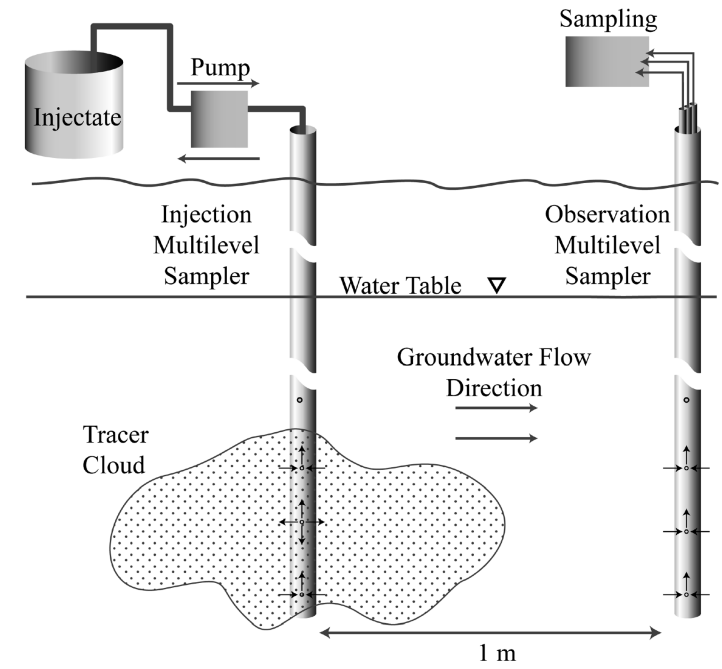

FIGURE 1. (A) Map showing location of wells sampled during September 2005 and the concentrations $\left(\mu \mathrm{g} \mathrm{L}^{-1}\right)$ of tetrachloroethene (PCE), 1,4-dichlorobenzene (DCB), 4-nonylphenol (NP), and sulfamethoxazole (SX). Also shown are the locations of the multilevel sampler arrays used for the transition zone (F347) and contaminated zone (S522) tracer experiments. (B) Schematic of natural gradient in situ tracer experimental procedures. [monitoring well F343-0036 (value after hyphen is depth in feet below land surface) is $0.19 \mathbf{~ k m}$ downgradient from the infiltration beds; F411-0065 is $1.7 \mathrm{~km}$ downgradient; F350-0064 and F350-0110 are 3.1 km downgradient; F375-0071 is 4.5 km downgradient].

pyroxenes, hematite, magnetite, and traces of clay minerals) with varying degrees of metal-oxide grain coatings (34). Sediment organic carbon (SOC) ranges from $<0.001-1 \%$ and varies as a function of particle size, mineralogy, and location (35). Dissolved oxygen in the uncontaminated groundwater overlying the plume (coming from surface water recharge to the unconfined aquifer) is near saturation, whereas the contamination plume has a steep vertical gradient with an anoxic core surrounded by oxic uncontaminated groundwater (36).

Groundwater Sampling and Analytical Procedures. During September 2005, groundwater was sampled from four wells located along a $4.5 \mathrm{~km}$ longitudinal transect of the contaminant plume (Figure 1A) using procedures described elsewhere (37). Water for OWC analysis was filtered through $0.45-\mu \mathrm{m}$ glass fiber filters and collected in 1-L amber glass bottles either unpreserved or preserved with $1 \%(\mathrm{v} / \mathrm{v})$ formalin. Unfiltered samples for volatile organic compound analysis were collected without headspace in $40-\mathrm{mL}$ amber glass vials. Samples were stored at $4{ }^{\circ} \mathrm{C}$ until analysis.

Continuous liquid-liquid extraction with methylene chloride and gas chromatography/mass spectrometry (GC/ MS) analysis was used to measure NP and other OWCs (7). Steroid hormones, including E2, were isolated using octadecylsilica solid-phase extraction with methanol elution, the methoxime/trimethylsilyl derivatives were formed (7), and analysis was by gas chromatography/tandem mass spectrometry (GC/MS/MS). Antibiotics, including SX, were analyzed (38) by hydrophilic-lipophilic balance solid-phase extraction with liquid chromatography/tandem mass spectrometry (LC/MS/MS). Volatile organic compounds, including PCE, were analyzed by purge and trap GC/MS (39). Additional OWCs were measured using methods described in the Supporting Information.

Tracer Tests. Natural gradient in situ tracer experiments $(31,40)$ were conducted during September 2006 at two multilevel sampler (MLS) arrays (Figure 1). Each MLS had 15 sampling ports consisting of different lengths of $0.3 \mathrm{~cm}$ inside diameter polyethylene tubing vertically spaced at approximately $0.3-\mathrm{m}$ intervals (37). The arrays have an extraction/ injection MLS and downgradient observation MLSs with sampling ports located at the same depths. The 3-dimensional nature of the contamination plume was used to conduct the tracer experiments in two discrete biogeochemical zones. The transition zone site (F347) was located $0.19 \mathrm{~km}$ downgradient from the infiltration beds at a depth representing the interface between the overlying oxic uncontaminated groundwater and the anoxic contamination plume (Figure $2 \mathrm{~A}$ and $\mathrm{B})$. The tracer experiment used an extraction/injection MLS (F347-M10) and an observation MLS (F347-M1) located $1.3 \mathrm{~m}$ downgradient. The contaminated zone site (S522) was located in the infiltration beds at a depth corresponding to the historical anoxic core of the plume, which has subsequently become oxic (Figure $2 \mathrm{C}$ and $\mathrm{D}$ ) as the result of natural attenuation following removal of the WWTP source in 1995 (41). This experiment used an extraction/injection MLS (S522M1) and an observation MLS (S522-M4) located $2.1 \mathrm{~m}$ downgradient. The water table altitude at the transition site was $14.5 \mathrm{~m}$ above mean sea level and at the contaminated site was $15.0 \mathrm{~m}$ above mean sea level.

The tracer experiments involved removing approximately $200 \mathrm{~L}$ of oxic groundwater from the extraction/injection MLS using a peristaltic pump, amending the groundwater with sodium bromide $\left(\mathrm{Br}^{-}\right), \mathrm{SX}, \mathrm{NP}$, and E2 (Table 1), and injecting the groundwater solution back into the aquifer over approximately $3 \mathrm{~h}$ at the port from which it was withdrawn (Figure 1B). Samples were collected from the injection MLS at 3-h intervals for 4 days, followed by daily sampling for 5 days. The low pumping rate $\left(<100 \mathrm{~mL} \mathrm{~min}^{-1}\right)$ from the sampling port had little effect on local groundwater flow, and the protocol minimized removal of tracer cloud volume $(<5 \%$ of the injection volume was withdrawn during each experiment). The downgradient observation MLSs were sampled daily for 10 days.

The NP used in the tracer experiments was a branchedchain isomeric mixture (Schenectady International, Schenectady, NY), and the $\mathrm{Br}^{-}$, SX, and E2 were high purity 


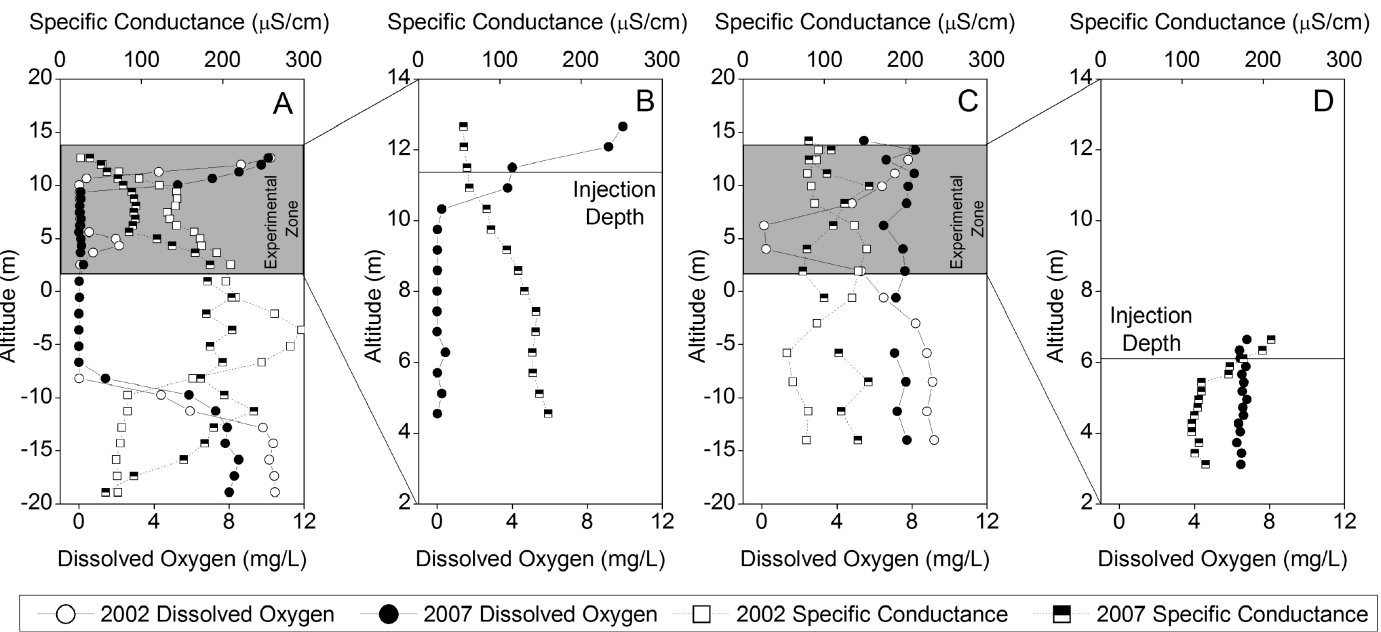

FIGURE 2. Groundwater geochemical conditions in the aquifer where natural gradient in situ tracer experiments were conducted. (A) Dissolved oxygen and specific conductance profiles for the F347 transition zone in July 2002 and June 2007. (B) Dissolved oxygen and specific conductance profiles for the F347 transition zone during the September 2006 tracer experiment. (C) Dissolved oxygen and specific conductance profiles for the S522 contaminated zone in July 2002 and June 2007. (D) Dissolved oxygen and specific conductance profiles for the S522 contaminated zone during the September 2006 tracer experiment. [In 2006 the water table altitude at F347 was $14.5 \mathrm{~m}$ above mean sea level and at $\mathrm{S} 522$ was $15.0 \mathrm{~m}$ above mean sea level].

\section{TABLE 1. Summary of Compounds Used in the Natural Gradient in Situ Groundwater Tracer Experiments ${ }^{d}$}

\begin{tabular}{|c|c|c|c|c|c|c|c|c|}
\hline Compound & Structure & Formula & $\begin{array}{c}\text { Molecular } \\
\text { Weight }\end{array}$ & CASRN & $\begin{array}{c}\begin{array}{c}\text { Water } \\
\text { Solubility }\end{array} \\
\mu g \mathrm{~L}^{-1}\end{array}$ & $\begin{array}{l}\log \\
K_{o w}\end{array}$ & $\begin{array}{c}\text { Trans- } \\
\text { ition } \\
C_{o} \\
\mu \mathrm{g} \mathrm{L}^{-1}\end{array}$ & $\begin{array}{c}\text { Contam- } \\
\text { inated } \\
C_{o} \\
\mu \mathrm{g} \mathrm{L}^{-1}\end{array}$ \\
\hline Bromide (Br") & & $\mathrm{NaBr}$ & 102.9 & $7647-15-6$ & $>1000000$ & -- & 99200 & 93600 \\
\hline Sulfamethoxazole (SX) & & $\mathrm{C}_{10} \mathrm{H}_{11} \mathrm{~N}_{3} \mathrm{O}_{3} \mathrm{~S}$ & 253.3 & $723-46-6$ & $610000^{\mathrm{a}}$ & $0.9^{\mathrm{a}}$ & 440 & 430 \\
\hline 4-Nonylphenol (NP) & & $\mathrm{C}_{15} \mathrm{H}_{24} \mathrm{O}$ & 220.4 & $84852-15-3$ & $4600^{b}$ & $4.0^{\mathrm{b}}$ & 190 & 170 \\
\hline $17 \beta$-Estradiol (E2) & & $\mathrm{C}_{18} \mathrm{H}_{24} \mathrm{O}_{2}$ & 272.4 & $50-28-2$ & $13000^{c}$ & $3.9^{\mathrm{c}}$ & 0.71 & 1.9 \\
\hline
\end{tabular}

${ }^{a}$ Abbreviations used in text given in parentheses: CASRN, Chemical Abstracts Services Registry Number; $K_{\text {ow }}$ octanol-water partition coefficient; $C_{0}$, concentration in the injection port following addition of tracers. ${ }^{b}$ Reference (52); ${ }^{c}$ Reference (53); ${ }^{d}$ Reference (54).

(>99\%) single-component standards (Sigma Aldrich, St. Louis, MO). Nominal concentrations (Table 1) were based on the sensitivity of the analytical methods, background concentrations, and a 100 -fold factor with respect to detection limits or background concentrations. Bromide was analyzed by ion chromatography (37), and SX, NP, and E2 were analyzed by enzyme linked immunosorbent assays (ELISA), following manufacturers procedures (Abraxis, Warminster, PA). Detection limits were $100 \mu \mathrm{g} \mathrm{L}^{-1}$ for $\mathrm{Br}^{-}, 2.5 \mu \mathrm{g} \mathrm{L}^{-1}$ for NP, $0.015 \mu \mathrm{g} \mathrm{L}^{-1}$ for SX, and $0.0015 \mu \mathrm{g}$ $\mathrm{L}^{-1}$ for E2. A subset of samples was analyzed for SX and NP using LC/MS/MS and GC/MS (as described above) to confirm the ELISA results.

Breakthrough-Curve Analysis. Groundwater velocity at the injection MLS $\left(v_{\text {inj }}\right)$ was estimated from the radius of the spherical tracer cloud $\left(x_{\mathrm{r}}\right)$ immediately after injection $\left(t_{0}\right)$ and the time after injection for concentrations to reach $C_{t} / C_{0}$ $=0.5\left(t_{0.5}\right)$, where $C_{t}$ is concentration at time $t$ and $C_{0}$ is concentration at $t_{0}$. Based on a 200 -L injection volume, an isotropic medium at the small scale of the tracer cloud $(32,33)$, and a porosity of 0.39 , the radius of a spherical tracer cloud symmetrically distributed around the injection port is $0.5 \mathrm{~m}$. At a flow velocity of $0.42 \mathrm{~m} \mathrm{~d}^{-1}$, a parcel of unperturbed groundwater would move $\sim 0.05 \mathrm{~m}$ during the injection period. Groundwater velocity at the observation MLS ( $\left.v_{\mathrm{obs}}\right)$ was estimated using moments analysis $(32,42)$ to determine time for the $\mathrm{Br}^{-}$center of mass to reach the sampling point $(\tau)$, and the distance between the injection and observation $\operatorname{MLS}\left(x_{1}\right)$. 


$$
v_{\mathrm{inj}}=\frac{x_{\mathrm{r}}}{t_{0.5}} ; v_{\mathrm{obs}}=\frac{x_{1}}{\tau}
$$

where

$$
\tau=\left[\int_{t_{\mathrm{b}}}^{t_{\mathrm{f}}} t C_{t} \mathrm{~d} t / \int_{t_{\mathrm{b}}}^{t_{\mathrm{f}}} C_{t} \mathrm{~d} t\right]
$$

and $t_{\mathrm{b}}$ is time at the beginning of breakthrough and $t_{\mathrm{f}}$ is time at the end of breakthrough (assuming an instantaneous pulse source, i.e., center of mass at $t_{0}$ is at $\left.x_{1}=0\right)$. Relative mass recovery $\left(M_{\text {rel }}\right)$ was determined by (43)

$$
M_{\text {rel }}=\left[\int_{t_{\mathrm{b}}}^{t_{\mathrm{f}}} \frac{C_{t}}{C_{0}} \mathrm{~d} t / \int_{t_{\mathrm{b}}}^{t_{\mathrm{f}}} \frac{\mathrm{Br}_{t}^{-}}{\mathrm{Br}_{0}^{-}} \mathrm{d} t\right] \times 100
$$

where $\mathrm{Br}_{0}^{-}$is concentration of $\mathrm{Br}^{-}$at $t_{0}$ and $\mathrm{Br}_{t}^{-}$is concentration of $\mathrm{Br}^{-}$at time $t$. Longitudinal dispersitivity $\left(\alpha_{\mathrm{L}}\right)$ of the conservative tracer $\mathrm{Br}^{-}$was determined by (44)

$$
\alpha_{\mathrm{L}}=\frac{x_{1}\left(\Delta t / t_{\text {peak }}\right)^{2}}{16 \ln 2}
$$

where $\Delta t$ is duration of breakthrough when $\mathrm{Br}^{-}$concentration was greater than $1 / 2$ peak concentration, and $t_{\text {peak }}$ is time to peak concentration. Relative retardation factor $\left(R_{f}\right)$ was determined by (45)

$$
R_{f}=\frac{\tau}{\tau_{\mathrm{Br}^{-}}}=1+\frac{\rho_{\mathrm{b}} K_{\mathrm{d}}}{\eta}
$$

where $\tau_{\mathrm{Br}}$ is time for the center of mass of the $\mathrm{Br}^{-}$cloud to pass the observation MLS, $\rho_{\mathrm{b}}$ is sediment bulk density, $K_{\mathrm{d}}$ is sediment water distribution coefficient (sediment concentration/water concentration), and $\eta$ is porosity. Calculation of $R_{f}$ using eq 5 assumes that initially the conservative and retarded compounds are uniformly distributed throughout the spherical cloud because of the rate-limited mass transfer during the 3-h injection phase when groundwater velocities are relatively fast compared to the ambient groundwater velocity. Sorption of nonpolar organic contaminants is controlled by sediment organic carbon (46) and can be expressed as the organic carbon normalized $K_{\mathrm{d}}\left(K_{\mathrm{oc}}=K_{\mathrm{d}} / f_{\mathrm{oc}}\right.$ where $f_{\text {oc }}=$ fraction sediment organic carbon), assuming a local equilibrium and linear sorption. The use of eq 5 ignores degradation, which can result in a negative bias to estimated $R_{f}$ values (42). However, consideration of such effects is beyond the scope of this investigation.

Microcosm Experiments. Laboratory microcosm experiments using aquifer sediments (47) were conducted to evaluate NP and E2 biodegradation potential. Sulfamethoxazole was not investigated because a ${ }^{14} \mathrm{C}$-labeled standard was not available. Sediment cores were collected adjacent to the MLS arrays at the same depths as the tracer experiments using hollow-stem auger drilling and a wireline piston core barrel. Uniform-ring-labeled ${ }^{14} \mathrm{C}$ 4-normal-NP (U-ring ${ }^{14} \mathrm{C}$ $4-n$-NP) had an activity of $52 \mu \mathrm{Ci} \mu \mathrm{mole}^{-1}$ and $4-{ }^{14} \mathrm{C}$ E2 had an activity of $54 \mu \mathrm{Ci} \mu$ mole $^{-1}$ ( $>99 \%$ purity, American Radiolabeled Chemicals, St. Louis, MO). The methods were calibrated with ${ }^{14} \mathrm{C} \mathrm{HCO}_{3}{ }^{-}$(98\% purity, Sigma Biochemicals, St. Louis, MO). Microcosms were prepared in triplicate and consisted of $10 \mathrm{~mL}$ serum vials with $5 \mathrm{~mL}$ of saturated sediment, $2 \mathrm{~mL}$ of sterile-deionized water, and an atmosphere of air. Duplicate sediment controls were prepared by autoclaving 3 times for $1 \mathrm{~h}$, and sediment free controls were prepared in the same manner. Microcosms were amended with approximately $0.02 \mu \mathrm{Ci}$ of the appropriate ${ }^{14} \mathrm{C}$-substrate to yield initial U-ring ${ }^{14} \mathrm{C} 4-n$-NP concentrations of $24 \mu \mathrm{g} \mathrm{L}^{-1}$ and $4-{ }^{14} \mathrm{C}$ E2 concentrations of $34 \mu \mathrm{g} \mathrm{L} \mathrm{L}^{-1}$. Microcosms were incubated in the dark at $23{ }^{\circ} \mathrm{C}$ for up to 54 days, and concentrations of ${ }^{14} \mathrm{CO}_{2}$ in the headspace were determined at approximately 7 -day intervals by isocratic packed column gas chromatography/radiometric detection. Headspace sample volumes were replaced with pure oxygen, and maintenance of oxic conditions was monitored. Dissolved phase concentrations were estimated using Henry's Law partition coefficients.

\section{Results and Discussion}

Plume Survey. The 2005 groundwater sampling (Figure 1A) confirmed the presence of contaminants, such as PCE, DCB, and NP, that were reported in the original 1985 sampling (12). Additional OWCs that were not analyzed in the earlier study were detected in the groundwater $(15 \%$ of the 212 compounds analyzed were detected; Supporting Information, Tables S1 and S2). The distribution of NP was restricted to the area near the infiltration beds, SX was detected along most of the plume, and E2 was not detected. Changes in the distributions of PCE, DCB, and NP between 1985 and 2005 indicate transport in the aquifer (groundwater travel distance during the 20 years between samplings was $\sim 3100 \mathrm{~m}$ ), consistent with earlier (12) estimated $R_{f}$ values (based on plume distributions) of 1.0 for PCE and DCB and 2.4 for NP. Despite changes in analytical methods, concentrations for the 1985 and 2005 samplings were similar.

Tracer Tests. Concentrations of $\mathrm{Br}^{-}$measured in the center of the tracer cloud at $t_{0}$ were $99 \%$ and $94 \%$ of the nominal values in the transition and contaminated zones. Concentrations of NP at $t_{0}$ were less than nominal values, likely, because of incomplete transfer of the neat NP standard and loss by sorption to the mixing containers and injection system. Concentrations of SX and E2 were greater than nominal values indicating potential analytical bias at high concentrations where large dilutions are required. The average relative percent difference for duplicate analyses was $0.7 \%$ for $\mathrm{Br}^{-}(n=12), 10.2 \%$ for SX $(n=40), 39.0 \%$ for NP ( $n=335)$, and $18.4 \%$ for E2 $(n=60)$. Results for the LC/ MS/MS and GC/MS analyses were correlated with the ELISA data, having $r^{2}$ values of 0.95 for SX $(n=327)$ and 0.90 for $\mathrm{NP}(n=33)$.

The $\mathrm{Br}^{-}$results (presented as $C_{\mathrm{t}} / C_{0}$, Figure 3 ), were used to estimate $v_{\text {inj }}$ and $v_{\text {obs }}$ (Table 2). In the transition zone experiment, $v_{\text {inj }}$ was $0.64 \mathrm{~m} \mathrm{~d}^{-1}$ and $v_{\text {obs }}$ was $0.58 \mathrm{~m} \mathrm{~d}^{-1}$, and in the contaminated zone experiment, $v_{\text {inj }}$ was $0.72 \mathrm{~m} \mathrm{~d}^{-1}$ and $v_{\text {obs }}$ was $0.65 \mathrm{~m} \mathrm{~d}^{-1}$. In addition to differences in the calculation methods, variability between $v_{\text {inj }}$ and $v_{\text {obs }}$ also reflects local heterogeneities in hydraulic conductivity (33) and transient disturbances during injection of the tracers. At the transition zone, the SX breakthrough curves coincided with the $\mathrm{Br}^{-}$curves indicating minimal retardation and minor mass loss, which is consistent with the reported behavior of SX in WWTP effluents and receiving waters $(9,48-51)$. The injection MLS breakthrough curves indicated greater sorption of NP $\left(R_{f}=1.8\right)$ than E2 $\left(R_{f}=0.9\right)$, but after $1.3 \mathrm{~m}$ of transport $R_{f}$ values were similar (1.4 and 1.3 , respectively). The $M_{\text {rel }}$ values after $1.3 \mathrm{~m}$ of transport were $42 \%$ and $37 \%$ for NP and E2 (Table 2), resulting in estimated in situ attenuation rates of $15 \% \mathrm{~d}^{-1}$ and $18 \% \mathrm{~d}^{-1}$ for NP and E2, respectively. Values of $\alpha_{\mathrm{L}}$ for $\mathrm{Br}^{-}$reflect aquifer characteristic controlled by the physical structure of the sediments $(32,33)$ and differed between the transition and contaminated sites. The calculated $\alpha_{\mathrm{L}}$ values for SX, NP, and E2 increased with increasing relative retardation and tailing of the breakthrough curve.

The $\mathrm{Br}^{-}$and SX breakthrough curves for the contaminated zone injection MLS (Figure 3, Table 2) had similar shapes and $C_{\mathrm{t}} / C_{0}$ values as for the transition zone. In contrast, NP sorption was greater in the contaminated zone than in the transition zone and there was substantial tailing of concentrations. In the contaminated zone experiment, E2 was added to the injection solution after $65 \%$ of the volume had been injected, which is reflected in faster breakthrough (Figure 


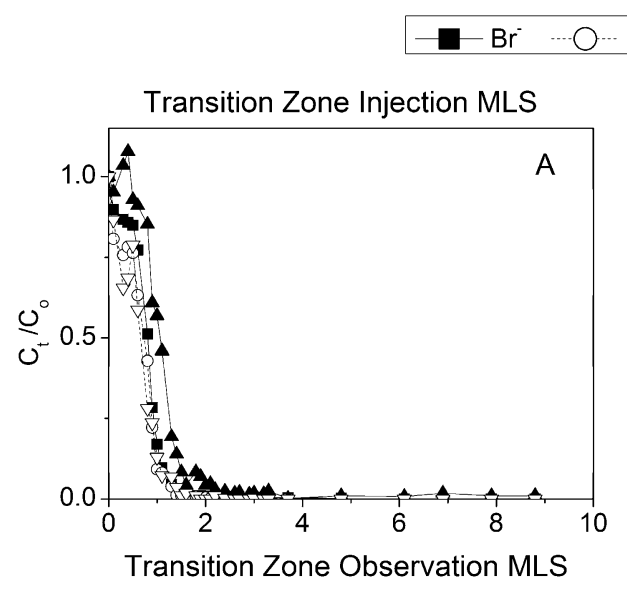

$\mathrm{SX} \quad \boldsymbol{\Delta} \mathrm{NP}-\nabla^{-} \mathrm{E} 2$
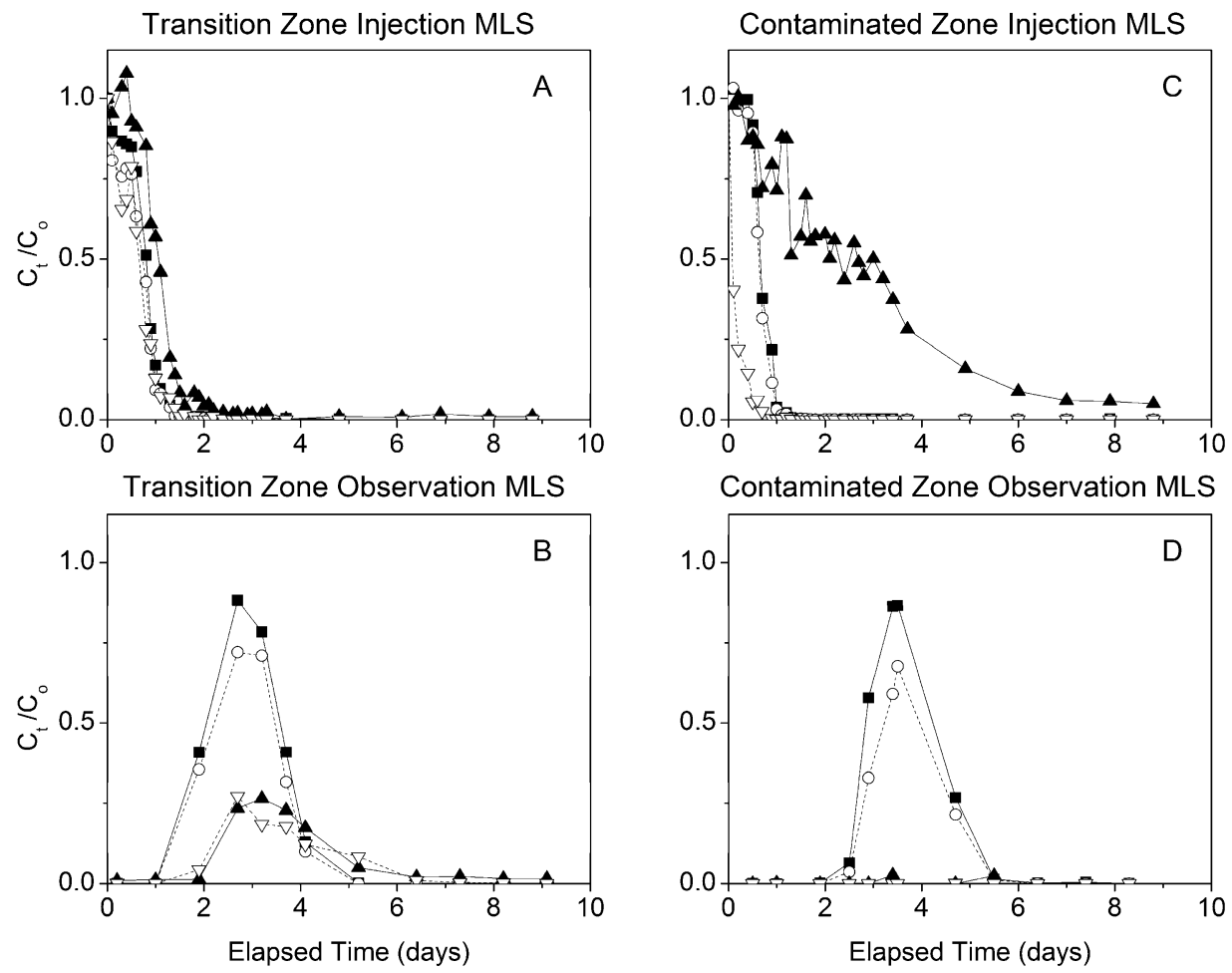

FIGURE 3. Breakthrough curves for bromide $\left(\mathrm{Br}^{-}\right)$, sulfamethoxazole (SX), 4-nonylphenol (NP), and 17 $\beta$-estradiol (E2) during the natural gradient in situ tracer experiments conducted in September 2006. (A) Transition zone (F347) injection multilevel sampler (MLS). (B) Transition zone observation MLS located $1.3 \mathrm{~m}$ downgradient. (C) Contaminated zone (S522) injection MLS. (D) Contaminated zone observation MLS located $2.1 \mathrm{~m}$ downgradient. $\left[C_{t} / C_{0}=\right.$ concentration at time $t /$ concentration at time $\left.t_{0}\right]$.
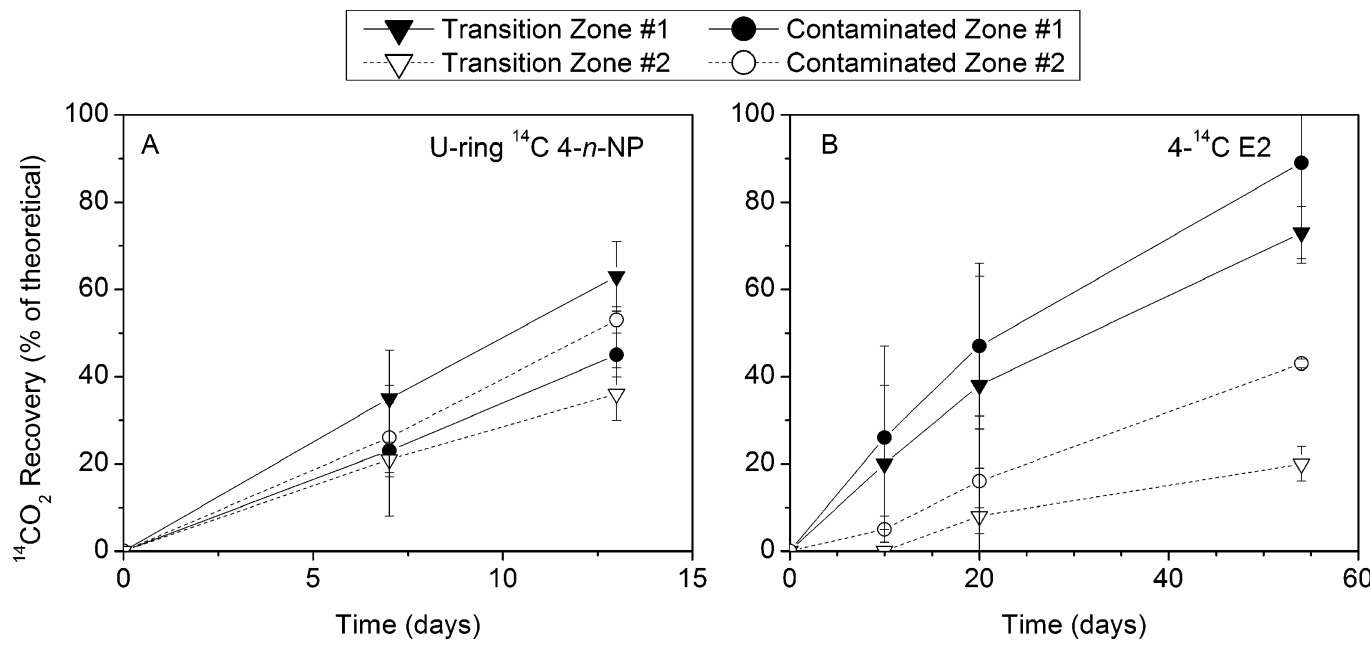

FIGURE 4. Results for oxic microcosm experiments using sediments collected from the transition zone (F347) and contaminated zone (S522). (A) Mineralization of uniformly ring-labeled ${ }^{14} \mathrm{C}$ 4-normal-NP (U-ring ${ }^{14} \mathrm{C} 4-n-\mathrm{NP}$ ) to ${ }^{14} \mathrm{CO}_{2}$. (B) Mineralization of $4-{ }^{14} \mathrm{C}$ $17 \beta$-estradiol $\left(4-{ }^{14} \mathrm{C} \mathrm{E2}\right)$ to ${ }^{14} \mathrm{CO}_{2}$. [Transition zone core 1 was collected at an altitude of $11.7-11.1 \mathrm{~m}$ above mean sea level and core 2 was collected at an altitude of 11.1-10.5 m above mean sea level (tracer injected at $11.5 \mathrm{~m}$ ); contaminated zone core 1 was collected at an altitude of $6.6-6.0 \mathrm{~m}$ above mean sea level and core 2 was collected at an altitude of $6.0-5.4 \mathrm{~m}$ above mean sea level (tracer injected at $6.1 \mathrm{~m}$ ); data are means \pm standard deviations for triplicate microcosms; no recovery of ${ }^{14} \mathrm{CO}_{2}$ was observed in autoclaved or sediment free control microcosms.]

3C) owing to the smaller radius of the tracer cloud. In contrast to $\mathrm{Br}^{-}$and SX, NP and E2 were not detected at the downgradient observation MLS during the course of the experiment. The estimated $R_{f}$ for NP determined from the injection MLS predicts a travel time of $>14$ days to the MLS, whereas the experiment was terminated after 10 days and the NP and E2 breakthrough curves were not captured. Greater sorption of NP in the contaminated zone than in the transition zone indicates geochemical het- erogeneity (34) with the sediments beneath the infiltration beds having enhanced sorption characteristics.

Retardation factors can be estimated from the $K_{\mathrm{oc}}$ values of the various compounds. The most water-soluble compound studied was SX (Table 1), which has a $\log K_{\text {oc }}$ of 1.8 $\mathrm{L} \mathrm{kg}^{-1}$ (52). Branch-chained NP has a $\log K_{\mathrm{oc}}$ of $4.0 \mathrm{~L} \mathrm{~kg}^{-1}$ (53) and E2 has a $\log K_{\mathrm{oc}}$ of $3.3 \mathrm{~L} \mathrm{~kg}^{-1}(54)$. Using the above log $K_{\mathrm{oc}}$ values, a bulk density of $1.59 \mathrm{~g} \mathrm{~cm}^{-3}$, a porosity of 0.39 , and a SOC of $0.005 \%\left(f_{\text {oc }}=0.00005\right)$ for the course to fine 
TABLE 2. Results from Breakthrough-Curve Analysis of the Natural Gradient in Situ Tracer and Sediment Microcosm Experiments Conducted in the Transition and Contaminated Zones in the Cape Cod Aquifer ${ }^{a}$

\begin{tabular}{|c|c|c|c|c|}
\hline parameter & $\begin{array}{c}\text { transition }^{b} \\
\text { injection } \\
\text { MLS }\end{array}$ & $\begin{array}{c}\text { transition }^{b} \\
\text { observation } \\
\text { MLS }\end{array}$ & $\begin{array}{l}\text { contaminated }^{c} \\
\text { injection } \\
\text { MLS }\end{array}$ & $\begin{array}{c}\text { contaminated } \\
\text { observation } \\
\text { MLS }\end{array}$ \\
\hline \multicolumn{5}{|l|}{ bromide $\left(\mathrm{Br}^{-}\right)$} \\
\hline$v_{\mathrm{inj}} ; v_{\mathrm{obs}}\left(\mathrm{m} \mathrm{d}^{-1}\right)$ & 0.64 & 0.58 & 0.72 & 0.65 \\
\hline$\tau(\mathrm{d})$ & 0.56 & 2.81 & 0.48 & 3.67 \\
\hline$\alpha_{L}(\mathrm{~cm})$ & & 4.71 & & 3.98 \\
\hline$R_{f}$ & 1.0 & 1.0 & 1.0 & 1.0 \\
\hline$M_{\text {rel }}(\%)$ & & 100 & & 100 \\
\hline \multicolumn{5}{|c|}{$\begin{array}{l}\text { sulfamethoxazole } \\
\text { (SX) }\end{array}$} \\
\hline$\tau(\mathrm{d})$ & 0.52 & 2.79 & 0.40 & 3.73 \\
\hline$\alpha_{L}(\mathrm{~cm})$ & & 4.89 & & 3.38 \\
\hline$R_{f}$ & 0.9 & 1.0 & 0.8 & 1.0 \\
\hline$M_{\text {rel }}(\%)$ & & 84 & & 72 \\
\hline \multicolumn{5}{|l|}{$\begin{array}{l}\text { 4-nonylphenol } \\
\text { (NP) }\end{array}$} \\
\hline$\tau(\mathrm{d})$ & 1.00 & 3.87 & 2.35 & \\
\hline$\alpha_{L}(\mathrm{~cm})$ & & 5.28 & & \\
\hline$R_{f}$ & 1.8 & 1.4 & 4.9 & \\
\hline$M_{\text {rel }}(\%)$ & & 42 & & \\
\hline $\begin{array}{l}\text { mineralization } \\
\left(\% d^{-1}\right)^{d}\end{array}$ & 3.8 & & 3.9 & \\
\hline \multicolumn{5}{|l|}{$\begin{array}{l}17 \beta \text {-estradiol } \\
(\mathrm{E} 2)\end{array}$} \\
\hline$\tau(\mathrm{d})$ & 0.50 & 3.50 & & \\
\hline$\alpha_{L}(\mathrm{~cm})$ & & 5.14 & & \\
\hline$R_{f}$ & 0.9 & 1.3 & & \\
\hline$M_{\text {rel }}(\%)$ & & 37 & & \\
\hline $\begin{array}{l}\text { mineralization } \\
\left.\qquad \% d^{-1}\right)^{d}\end{array}$ & 0.9 & & 1.3 & \\
\hline
\end{tabular}

${ }^{a}$ Abbreviations used in text given in parentheses: [MLS, multilevel sampler; $\mathrm{m}$, meters of transport; $v_{\text {inj, }}$ average groundwater velocity at the injection MLS; $v_{\text {obs, }}$ average groundwater velocity at the observation MLS; $\tau$, hydraulic residence time; $\alpha_{L}$, longitudinal dispersitivity; $R_{f}$, relative retardation factor; $M_{\text {rel, }}$ relative mass recovery; mineralization, average initial linear mineralization rate. ${ }^{b}$ Tracer pulse was injected into the transition zone at an altitude of $11.5 \mathrm{~m}$ above mean sea level over $3.1 \mathrm{~h}$, and the observation MLS was located $1.3 \mathrm{~m}$ downgradient from the injection MLS; ${ }^{c}$ Tracer pulse was injected into the contaminated zone at an altitude of $6.1 \mathrm{~m}$ above mean sea level over $3.3 \mathrm{~h}$, and the observation MLS was located $2.1 \mathrm{~m}$ downgradient from the injection MLS; ${ }^{d}$ Mineralization determined from the amount of ${ }^{14} \mathrm{CO}_{2}$ recovered (in $\%$ of theoretical) and duration of the experiment.

grained sand (35) results in calculated $R_{f}$ values of 1.0 for SX, 3.0 for NP, and 1.4 for E2, consistent with observed transport (Table 2). Similar natural gradient in situ tracer experiments with LAS at the transition zone site showed chromatographic separation of isomers with varying alkyl-chain lengths with $R_{f}$ values ranging from $1.0-2.9(55,56)$. Fractionation of NP isomers was not observed (based on GC/MS results), consistent with positional isomers on a single 9 carbon alkyl chain.

Microcosm Experiments. Attenuation of NP and E2 was observed during the natural gradient tracer tests in the transition zone, presumably owing to biotransformation. The sediment microcosm experiments showed that $30-60 \%$ of the U-ring ${ }^{14} \mathrm{C} 4$ - $n$-NP was recovered as ${ }^{14} \mathrm{CO}_{2}$ in 13 days, with initial linear rates of mineralization ranging from $3.8-3.9 \% \mathrm{~d}^{-1}$ (Figure 4 ; Table 2 ). The $4-n$-NP isomer used in the microcosm experiments is not a component of technical NP formulations, but the linear nature of the side chain makes it more biodegradable than the branched-chain isomers and thus an indicator of maximum biodegradation potential. There was no difference in U-ring ${ }^{14} \mathrm{C} 4-n$-NP mineralization between the transition and contaminated zones. Mineralization of $4-{ }^{14} \mathrm{C}$ E2 also was observed, with $20-90 \%$ of the substrate recovered as ${ }^{14} \mathrm{CO}_{2}$ in 54 days. As observed for U-ring ${ }^{14} \mathrm{C} 4$ - $n$-NP, there was no difference in $4-{ }^{14} \mathrm{CE} 2$ mineralization between the transition and contaminated zones although there was a difference with depth.

Attenuation rates observed in the transition zone observation MLS was greater than in the laboratory microcosms suggesting that other factors are influencing the estimates. Attenuation in the field does not necessarily indicate mineralization, but could be due to formation of metabolites such as conversion of E2 to estrone (57). Transformation products were not measured as part of this study. Although microcosm and field determined removals are not directly comparable (microcosms were designed to evaluate potential rather than mimic in situ conditions), the data demonstrate that the subsurface microbial community is capable of mineralizing 4- $n$-NP and E2. Similar oxic microcosm experiments conducted with stream sediments reported initial linear rates of mineralization of $7-10 \% \mathrm{~d}^{-1}$ for U-ring ${ }^{14} \mathrm{C}$ $4-n$-NP (47) and $2-6 \% \mathrm{~d}^{-1}$ for $4-{ }^{14} \mathrm{C} \mathrm{E} 2$ (58). Mineralization of E2 under oxic condition by WWTP solids (57) had an average removal of $74 \% \mathrm{~d}^{-1}$. Although microcosm experiments were not conducted with SX, the literature on its oxic biodegradation reports mixed results. At low biomass concentrations typical of natural waters, only $4 \%$ SX degradation was observed in laboratory experiments over 28 days (48). Under the high biomass conditions of a WWTP, SX biodegradation can exceed $90 \%(49-51)$.

Implications. This study documents the subsurface behavior of WWTP effluent derived contaminants at a range of spatial scales from meters to kilometers and temporal scales from hours to decades. The plume distributions indicate long-range transport and persistence of OWCs, whereas the natural gradient in situ tracer experiments were more controlled and provided quantitative data at a localized spatial and temporal scale. Data from both the injection and observation MLSs were used to maximize the information obtained from the resource intensive tracer experiments. For example, at the contaminated site the injection MLS data show that NP transport is retarded by sorption and an $R_{f}$ can be estimated. Because breakthrough was not observed in the downgradient observation MLS, $R_{f}$ cannot be estimated from the field results. Although hydraulically different (one is natural gradient and the other is induced gradient), single MLS pulsed experiments (40) are similar to single well push-pull experiments (59) in that they can be completed in relatively short times, only require one well, and do not require a priori knowledge of local flow conditions. Natural gradient pulsed tracer test methods using downgradient MLSs $(40,55)$ provide more integrated spatial and temporal data for defining hydraulic parameters and are less influenced by disturbances in the injection well. However, they require detailed knowledge of local hydraulic conditions, an appropriately located 3-dimensional sampling grid, and greater logistical resources.

The co-transport of SX and $\mathrm{Br}^{-}$suggests that SX may be a useful tracer of subsurface contamination by WWTP effluent. The occurrence and transport of SX in the contamination plume over kilometers and decades indicates that it is resistant to natural attenuation in the subsurface environment. Previous studies have shown cotransport of free living bacteria and OWCs in the downgradient wells (60) in which SX was detected, indicating long-term exposure of the microbial community to antimicrobial compounds. Although the effect of antibiotics on the biotransformation of co-occurring OWCs is not known, previous in situ experiments at the Cape Cod site showed that high concentrations of antibiotics eliminated hydrogen consumption, a sensitive measure of subsurface microbial activity (61). 
Retardation of NP transport by sorption to the aquifer sediments and mass loss by biotransformation under oxic conditions illustrates the complexities of natural attenuation. As suggested by the plume scale distributions, aquifer degradation rates must be slower than those determined in laboratory microcosm and small scale field experiments. This indicates that additional factors such as hydrodynamics, temperature, oxygenation conditions, nutrient limitations, and microbial ecology also control the fate of OWCs. Sorption of NP to the aquifer sediments occurred over the WWTP effluent disposal history at the site, and its persistence under anoxic conditions (47) resulted in an extensive contamination plume near the infiltration beds. Concentrations and distributions of NP determined in the 2005 sampling were relatively unchanged from results determined 20 years earlier. Concentrations of NP measured in the groundwater were similar to values reported for WWTP effluents and impacted surface waters $(5,7,8,11)$, and were near those shown to induce biological effects $(19,20,62,63)$.

The occurrence of OWCs such as SX, NP, and E2 at other impacted groundwater sites $(14,15,64)$ and in septic tank effluents (65) indicates their potential as groundwater contaminants, and understanding their behavior under different hydrological, geochemical, and management conditions requires further study. Once introduced into the aquifer, depending on the biogeochemical environment and individual chemical characteristics, contaminants can persist and be transported over long distances.

\section{Acknowledgments}

We appreciate the assistance of Luke Parsons, Mike Focazio, Kimberly Campo, Jenny Savoie, Laural Standly, Chris Swartz, Greg Brown, James Gray, Doug Kent, Ed Furlong, Deborah Repert, Steve Zaugg, and Kathy Conn. This research was supported by the U.S. Geological Survey National Research Program and the U.S. Geological Survey Toxic Substances Hydrology Program. Use of trade names is for identification purposes and does not imply endorsement by the U.S. Government.

\section{Supporting Information Available}

Descriptions of the chemical analysis methods and results from the 2005 groundwater sampling. This material is available free of charge via the Internet at http:/ / pubs.acs.org.

\section{Literature Cited}

(1) National Research Council. Issues in Potable Reuse-The Viability of Augmenting Drinking Water Supplies with Reclaimed Water, National Academy Press: Washington, DC, 1998.

(2) Solley, W. B.; Pierce, R. R.; Perlman, H. A. Estimated use of water in the United States in 1995. U. S. Geological Survey Circular 1200; U. S. Geological Survey: 1998.

(3) Alley, W. M.; Reilly, T. E.; Franke, O. L. Sustainability of GroundWater Resources; U. S. Geological Survey Circular 1186; U. S. Geological Survey: 1999.

(4) Daughton, C. G.; Ternes, T. A. Pharmaceuticals and personal care products in the environment: Agents of subtle change. Environ. Health. Perspect. 1999, 107 (Suppl 6), 907-938.

(5) Ahel, M.; Giger, W.; Koch, M. Behavior of alkylphenol polyethoxylate surfactants in the aquatic environment. 1. Occurrence and transformation in sewage treatment. Water Res. 1994, 28, 2029-2039.

(6) Ternes, T. A. Occurrence of drugs in German sewage treatment plants and rivers. Water Res. 1998, 32, 3245-3260.

(7) Barber, L. B.; Brown, G. K.; Zaugg, S. D. Potential endocrine disrupting organic chemicals in treated municipal wastewater and river water. In Analysis of Environmental Endocrine Disruptors; Keith, L. H., Jones-Lepp, T. L., Needham, L. L., Eds.; ACS Symposium Series 747; American Chemical Society: Washington, DC, 2000.

(8) Kolpin, D. W.; Furlong, E. T.; Meyer, M. T.; Thurman, E. M.; Zaugg, S. D.; Barber, L. B.; Buxton, H. T. Pharmaceuticals, hormones, and other organic wastewater contaminants in U.S. streams, 1999-2000: A national reconnaissance. Environ. Sci. Technol. 2002, 36, 1202-1211.
(9) Glassmeyer, S. T.; Furlong, E. T.; Kolpin, D. W.; Cahill, J. D.; Zaugg, S. D.; Werner, S. L.; Meyer, M. T.; Kryak, D. D. Transport of chemical and microbial compounds from known wastewater discharges: Potential for use as indicators of human fecal contamination. Environ. Sci. Technol. 2005, 39, 5157-5169.

(10) Lindqvist, N.; Tuhkanen, T.; Kronberg, L. Occurrence of acidic pharmaceuticals in raw and treated sewages and in receiving waters. Water Res. 2005, 39, 2219-2228.

(11) Barber, L. B.; Murphy, S. F.; Verplanck, P. L.; Sandstrom, M. W.; Taylor, H. E.; Furlong, E. T. Chemical loading into surface water along a hydrological, biogeochemical, and land use gradient: A holistic watershed approach. Environ. Sci. Technol. 2006, 40, 475-486.

(12) Barber, L. B., II.; Thurman, E. M.; Schroeder, M. P.; LeBlanc, D. R. Long-term fate of organic micropollutants in sewagecontaminated ground water. Environ. Sci. Technol. 1988, 22, 205-211.

(13) Leenheer, J. A.; Rostad, C. E.; Barber, L. B.; Schroeder, R. A.; Anders, R.; Davisson, M. L. Determination of the nature and chlorine disinfection by-products of organic constituents from reclaimed water in ground water, Los Angeles County, California. Environ. Sci. Technol. 2001, 35, 3869-3876.

(14) Swartz, C. H.; Reddy, S.; Benotti, M. J.; Yin, H.; Barber, L. B.; Brownawell, B. J.; Rudel, R. Steroid estrogens, nonylphenol ethoxylate metabolites, and other wastewater contaminants in groundwater affected by a residential septic system on Cape Cod, MA. Environ. Sci. Technol. 2006, 40, 4894-4902.

(15) Godfrey, E.; Woessner, W. W.; Benotti, M. J. Pharmaceuticals in on-site sewage effluent and ground water, western Montana. Ground Water 2007, 45, 263-271.

(16) Barnes, K. K.; Kolpin, D. W.; Furlong, E. T.; Zaugg, S. D.; Meyer, M. T.; Barber, L. B. A national reconnaissance of pharmaceuticals and other organic wastewater contaminants in the United States-(I) Groundwater. Sci. Total Environ. 2008, 402, 192200.

(17) Jobling, S.; Nolan, M.; Tyler, C. R.; Brighty, G.; Sumpter, J. P. Widespread sexual disruption in wild fish. Environ. Sci. Technol. 1998, 32, 2498-2506.

(18) Norris, D. O.; Carr, J. A., Eds. Endocrine Disruption: Biological Bases for Health Effects in Wildlife and Humans; Oxford University Press: Oxford, U.K., 2006.

(19) Barber, L. B.; Lee, K. E.; Swackhamer, D. L.; Schoenfuss, H. L. Reproductive responses of male fathead minnows exposed to wastewater treatment plant effluent, effluent treated with XAD8 resin, and an environmentally relevant mixture of alkylphenol compounds. Aquat. Toxicol. 2007, 82, 36-46.

(20) Vajda, A. M.; Barber, L. B.; Gray, J. L.; Lopez, E. M.; Woodling, J. D.; Norris, D. O. Reproductive disruption in fish downstream of an estrogenic wastewater effluent. Environ. Sci. Technol. 2008, 42, 3407-3414.

(21) Johnson, A. C.; Sumpter, J. P. Removal of endocrine-disrupting chemicals in activated sludge treatment works. Environ. Sci. Technol. 2001, 35, 4697-4703.

(22) Miao, X. S.; Bishay, F.; Chen, M.; Metcalfe, C. D. Occurrence of antimicrobials in the final effluents of wastewater treatment plants in Canada. Environ. Sci. Technol. 2004, 38, 3533-3541.

(23) Karthikeyan, K. G.; Meyer, M. T. Occurrence of antibiotics in wastewater treatment facilities in Wisconsin, USA. Sci. Total Environ. 2006, 361, 196-207.

(24) Costanzo, S. D.; Murby, J.; Bates, J. Ecosystem response to antibiotics entering the aquatic environment. Mar. Pollut. Bull. 2005, 51, 218-223.

(25) Kümmerer, K. Resistance in the environment. J. Antimicrob. Chemother. 2004, 54, 311-320.

(26) LeBlanc, D. R. Sewage Plume in a Sand and Gravel Aquifer, Cape Cod, Massachusetts; U. S. Geological Survey Water-Supply Paper 2218; U.S. Geological Survey: 1984.

(27) U. S. Geological Survey. Cape Cod Toxic Substances Hydrology Research Site. http://ma.water.usgs.gov/capecodtoxics.

(28) Thurman, E. M.; Barber, L. B., Jr.; LeBlanc, D. R. Movement and fate of detergents in ground water-A field study. J. Contam. Hydrol. 1986, 1, 143-161.

(29) Field, J. A.; Barber, L. B., II.; Thurman, E. M.; Moore, B. L.; Lawrence, D. L.; Peake, D. A. Fate of alkylbenzenesulfonates and dialkyltetralinsulfonates in sewage contaminated ground water. Environ. Sci. Technol. 1992, 26, 1140-1148.

(30) Field, J. A.; Leenheer, J. A.; Thorn, K. A.; Barber, L. B., II.; Rostad, C.; Macalady, D. L.; Daniel, S. R. Identification of persistent anionic-surfactant derived chemicals in sewage effluent and ground water. J. Contam. Hydrol. 1992, 9, 55-78. 
(31) LeBlanc, D. R.; Garabedian, S. P.; Hess, K. M.; Gelhar, L. W.; Quadri, R. D.; Stollenwerk, K. G.; Wood, W. W. Large-scale natural gradient tracer test in sand and gravel, Cape Cod, Massachusetts. 1. Experimental design and observed tracer movement. Water Resour. Res. 1991, 27, 895-910.

(32) Garabedian, S. P.; LeBlanc, D. R.; Gelhar, L. W.; Celia, M. A. Large-scale natural gradient tracer test in sand and gravel, Cape Cod, Massachusetts. 2. Analysis of spatial moments for a nonreactive tracer. Water Resour. Res. 1991, 27, 911-924.

(33) Hess, K. M.; Wolf, S. H.; Celia, M. A. Large-scale natural gradient tracer test in sand and gravel, Cape Cod, Massachusetts. 3. Hydraulic conductivity variability and calculated macrodispersivities. Water Resour. Res. 1992, 28, 2011-2027.

(34) Barber, L. B., II.; Thurman, E. M.; Runnells, D. D. Geochemical heterogeneity in a sand and gravel aquifer - Effect of sediment mineralogy and particle size on the sorption of chlorobenzenes. J. Contam. Hydrol. 1992, 9, 35-54.

(35) Barber, L. B., II. Sorption of chlorobenzenes by Cape Cod aquifer sediments. Environ. Sci. Technol. 1994, 28, 890-897.

(36) Smith, R. L.; Howes, B. L.; Duff, J. H. Denitrification in nitratecontaminated groundwater: Occurrence in steep vertical geochemical gradients. Geochim. Cosmochim. Acta 1991, 55, $1815-1825$.

(37) Savoie, J.; LeBlanc, D. R. Water-Quality Data and Methods of Analysis for Samples Collected near a Plume of SewageContaminated Ground Water, Ashumet Valley, Cape Cod, Massachusetts, 1993-1994; U. S. Geological Survey Water Resource Investigation Report 97-4269; U.S. Geological Survey: 1998.

(38) Meyer, M. T.; Lee, E. A.; Ferrell, G. F.; Bumgarner, J. E.; Varnes, J. Evaluation of Tandem off-Line and on-Line Solid-Phase Extraction with Liquid Chromatography/Electrospray IonizationMass Spectrometry for the Analysis of Antibiotics in Ambient Water and Comparison to an Independent Method; U. S. Geological Survey Scientific Investigation Report 2007-5021; U. S. Geological Survey: 2007.

(39) U. S. Environmental Protection Agency. Method 8620B. In Methods for the Determination of Organic Compounds in Drinking Water; Supplement III, 500 Series, U. S. EPA EPA600/R-95-131; U.S. Environmental Protection Agency: Washington, DC, 1995.

(40) Smith, R. L.; Baumgartner, L. K.; Miller, D. N.; Repert, D. A.; Böhlke, J. K. Assessment of nitrification potential in groundwater using short term, single-well injection experiments. Microbial Ecol. 2006, 51, 22-35.

(41) Repert, D. A.; Barber, L. B.; Hess, K. M.; Keefe, S. H.; Kent, D. B.; LeBlanc, D. R.; Smith, R. L. Long-term natural attenuation of carbon and nitrogen within a groundwater plume after removal of the treated wastewater source. Environ. Sci. Technol. 2006, 40, 1154-1162.

(42) Pang, L.; Goltz, M.; Close, M. Application of the method of temporal moments to interpret solute transport with sorption and degradation. J. Contam. Hydrol. 2003, 60, 123-134.

(43) Harvey, R. W.; George, L. H.; Smith, R. L.; LeBlanc, D. R. Transport of microspheres and indigenous bacteria through a sandy aquifer: Results of natural- and forced-gradient tracer experiments. Environ. Sci. Technol. 1989, 23, 51-56.

(44) Harvey, R. W.; Garabedian, S. P. Use of colloid filtration theory in modeling movement of bacteria through a contaminated sandy aquifer. Environ. Sci. Technol. 1991, 25, 178-185.

(45) Freeze, R. A.; Cherry, J. A. Groundwater; Prentice-Hall, Inc.: Englewood Cliffs, NJ, 1979.

(46) Schwarzenbach, R. P.; Westall, J. Transport of nonpolar organic compounds from surface water to groundwater - Laboratory sorption studies. Environ. Sci. Technol. 1981, 15, 1360-1367.

(47) Bradley, P. M.; Barber, L. B.; Kolpin, D. W.; McMahon, P. B.; Chapelle, F. H. Potential for 4-n-nonylphenol biodegradation in stream sediments. Environ. Toxicol. Chem. 2008, 27, 260265.
(48) Alexy, R.; Kümpel, T.; Kümmerer, K. Assessment of degradation of 18 antibiotics in the closed bottle test. Chemosphere 2004, 57, 505-512.

(49) Perez, S.; Eichorn, P.; Aga, D. S. Evaluating the biodegradability of sulfamethazine, sulfamethoxazole, sulfathiazole, and trimethoprim at different stages of sewage treatment. Environ. Toxicol. Chem. 2005, 24, 1361-1367.

(50) Batt, A. L.; Kim, S.; Aga, D. S. Comparison of the occurrence of antibiotics in four full-scale wastewater treatment plants with varying designs and operations. Chemosphere 2007, 68, 428435.

(51) Göbel, A.; McArdell, C. S.; Joss, A.; Siegrist, H.; Giger, W. Fate of sulfonamides, macrolides, and trimethoprim in different wastewater treatment technologies. Sci. Total Environ. 2007, 372, 361-371.

(52) Drillia, P.; Stamatelatou, K.; Lyberatos, G. Fate and mobility of pharmaceuticals in solid matrices. Chemosphere 2005, 60, 10341044.

(53) Düring, R. A.; Krahe, S.; Gäth, S. Sorption behavior of nonylphenol in terrestrial soils. Environ. Sci. Technol. 2002, 36, 40524057.

(54) Lee, L. S.; Strock, T. J.; Sarmah, A. K.; Rao, P. S. C. Sorption and dissipation of testosterone, estrogens, and their primary transformation products in soils and sediment. Environ. Sci. Technol. 2003, 37, 4098-4105.

(55) Krueger, C. J.; Barber, L. B.; Metge, D. W.; Field, J. A. Fate and transport of linear alkylbenzene sulfonate in a sewagecontaminated aquifer: A comparison of natural-gradient pulsed tracer tests. Environ. Sci. Technol. 1998, 32, 1134-1142.

(56) Krueger, C. J.; Radakovich, K. M.; Sawyer, T. E.; Barber, L. B.; Smith, R. L.; Field, J. A. Biodegradation of the surfactant linear alkylbenzenesulfonate in sewage-contaminated groundwater: A comparison of column experiments and field tracer tests. Environ. Sci. Technol. 1998, 32, 3954-3961.

(57) Layton, A. C.; Gregory, B. W.; Seward, J. R.; Schultz, T. W.; Sayler, G. S. Mineralization of steroidal hormones by biosolids in wastewater treatment systems in Tennessee U.S.A. Environ. Sci. Technol. 2000, 34, 3925-3931.

(58) Bradley, P. M.; Barber, L. B.; Chapelle, F. H.; Gray, J. L.; Kolpin, D. W.; McMahon, P. B., Biodegradation of $17 \beta$-estradiol, estrone and testosterone in stream sediments. Environ. Sci. Technol. 2009, 43, 1902-1910.

(59) Istok, J. D.; Field, J. A.; Schroth, M. H.; Davis, B. M.; Dwarakanath, V. Single-well "push-pull" partitioning tracer test for NAPL detection in the subsurface. Environ. Sci. Technol. 2002, 36, 2708-2716.

(60) Harvey, R. W.; Barber, L. B., II. Associations of free-living bacteria and dissolved organic compounds in a plume of contaminated ground water. J. Contam. Hydrol. 1992, 9, 91-103.

(61) Harris, S. H.; Smith, R. L.; Suflita, J. M. In situ hydrogen consumption kinetics as an indicator of subsurface microbial activity. FEMS Microbial. Ecol. 2007, 60, 220-228.

(62) U. S. Environmental Protection Agency. Aquatic life ambient water quality criteria - Nonylphenol FINAL; U. S. EPA EPA 822R-05-005; U.S. Environmental Protection Agency: Washington, DC, 2005.

(63) Schoenfuss, H. L.; Bartell, S. E.; Bistodeau, T. B.; Cediel, R. A.; Grove, K. J.; Zintek, L.; Lee, K. E.; Barber, L. B. Impairment of the reproductive potential of male fathead minnows by environmentally relevant exposures to 4-nonylphenol. Aquat. Toxicol. 2008, 86, 91-98.

(64) Rudel, R. A.; Geno, P.; Melly, S. J.; Sun, G.; Brody, J. G. Identification of alkylphenols and other estrogenic phenolic compounds in wastewater, septage, and groundwater on Cape Cod, Massachusetts. Environ. Sci. Technol. 1998, 32, 861-869.

(65) Conn, K. M.; Barber, L. B.; Brown, G. K.; Siegrist, R. L. Occurrence and fate of organic contaminants during onsite wastewater treatment. Environ. Sci. Technol. 2006, 40, 7358-7366.

ES803292V 